\title{
Increased expression of IL-10 and IL-12 (p40) mRNA in Helicobacter pylori infected gastric mucosa: relation to bacterial cag status and peptic ulceration
}

\author{
N Hida, T Shimoyama Jr, P Neville, M F Dixon, A T R Axon, T Shimoyama Sr, \\ J E Crabtree
}

\begin{abstract}
Aims-To investigate interleukin (IL)-12 (p40) and IL-10 mRNA expression levels in the gastric mucosa in relation to $H$ pylori cag status, peptic ulceration, and histopathology.

Methods-In 81 dyspeptic patients, antral and corpus biopsies were taken for reverse transcriptase polymerase chain reaction (RT-PCR) and histology. G3PDH (control) and IL-10 and IL-12 were coamplified in a duplex PCR and the ratios of cytokines to G3PDH were determined. Bacterial ureA and cagA status was determined by RT-PCR.

Results-IL-10 mRNA expression in both the antral and corpus mucosa was greater $(p<0.01)$ in cagA positive infection than in $H$ pylori negative patients with histologically normal mucosa. No increase in IL-10 mRNA expression was observed in cagA negative infection. Both in the antral and corpus mucosa, IL-12 mRNA expression was greater $(p<0.05)$ in cagA positive than in cagA negative infection and uninfected patients with normal gastric mucosa. In cagA positive infection, there was a correlation between IL-10 and IL-12 mRNA expression in both the antral mucosa $(r=0.515, \mathrm{p}<0.01)$ and the corpus mucosa $(r=0.6, p<0.005)$. IL-12 mRNA expression in the antral mucosa was significantly more frequent in $H$ pylori positive patients with duodenal ulcer than in those with gastric ulcer or nonulcer dyspepsia. No difference was observed in IL-10 mRNA expression in relation to endoscopic diagnosis. Conclusions-CagA positive $H$ pylori infection is associated with increased IL-10 and IL-12 mRNA expression. The increased expression of IL-12 mRNA in the majority of patients with duodenal ulcer suggests that Th1 responses may predominate and play a role in the pathogenesis of duodenal ulceration.

(f Clin Pathol 1999;52:658-664)
\end{abstract}

Keywords: $H$ pylori; cag pathogenicity island; IL-10; IL-12; peptic ulcer

In Helicobacter pylori infection, the inflammatory immune response generated by the bacterium is likely to be a major factor contributing to gastric mucosal damage. ${ }^{1}$ Cytokines play a critical role in the regulation of initial acute inflammation and specific $\mathrm{T}$ and $\mathrm{B}$ cell responses induced by $H$ pylori. Recent studies in the $H$ felis mouse model suggest an important role of specific $\mathrm{T}$ cell responses in the induction of gastric mucosal inflammation. ${ }^{23}$ Both in mice and humans, CD4+ $\mathrm{T}$ helper (Th) cells can be divided into two main subsets, based on their differential cytokine production profiles. ${ }^{45}$ Human Th1 cells, which promote cell mediated immune responses, produce high levels of interferon $\gamma$ (IFN $\gamma$ ) but no IL-4 and IL-5, whereas Th2 cells, which induce humoral responses, produce IL-4 and IL-5 but no IFN $\gamma .{ }^{4}$ Cytokines, such as interleukin (IL)-12 and IL-10, are known to influence the differentiation of $\mathrm{T}$ helper cells.

IL-12 is a heterodimeric cytokine composed of two unrelated chains, p40 and p35, encoded by separate genes located on different chromosomes. ${ }^{6}$ The expression of the $\mathrm{p} 40$ gene is specific to IL-12 producing cells, while the p35 gene expression is constitutively expressed in different cell types. The production of both chains is required to form a biologically active heterodimer (p70). ${ }^{7}$ IL-12 is produced mostly by phagocytic cells in response to bacterial infection. Together with IFN $\gamma$, IL-12 induces the differentiation of Th1 cells and inhibits Th2 responses. ${ }^{6}$

IL-10 was initially described as a product of Th2 cells which inhibits the secretion of cytokines by Th1 cells. ${ }^{8}$ However, recent studies have shown that human IL-10 is not strictly a Th2 specific cytokine. ${ }^{9}$ IL-10 inhibits the differentiation of Th1 cells by suppressing IL-12 production from accessory cells. ${ }^{6}{ }^{10}$ IL-10 also has anti-inflammatory properties, inhibiting the production of proinflammatory cytokines and chemokines from macrophages and neutrophils. ${ }^{11}$

Current evidence from both human ${ }^{12-15}$ and murine studies $^{2} 3$ has shown that Th1 responses predominate during chronic helicobacter associated gastritis. A recent study on $H$ pylori specific gastric $\mathrm{T}$ cell clones suggests that the mucosal $\mathrm{T}$ cell response to $H$ pylori in patients with peptic ulceration is more polarised towards a Th1 profile than in those with chronic gastritis only. ${ }^{12}$ Only 11 subjects were studied and all were infected with cytotoxin associated gene A (cagA) positive strains. ${ }^{12}$ In vivo infection with $H$ pylori strains expressing cagA, which is part of the cag pathogenicity island (PAI), is associated with enhanced 
Table 1 Oligonucleotide primers for reverse transcriptase polymerase chain reaction

\begin{tabular}{llll}
\hline Gene & Primer & $\begin{array}{l}\text { Expected product } \\
\text { size }(\mathrm{bp})\end{array}$ \\
\hline G3PDH & $\begin{array}{l}\text { Sense } \\
\text { Antisense }\end{array}$ & $\begin{array}{l}\text { GAGTCAACGGATTTGGTCGT } \\
\text { GGTGCCATGGAATTTGCCAT }\end{array}$ & 158 \\
IL-10 & $\begin{array}{l}\text { Sense } \\
\text { Antisense }\end{array}$ & $\begin{array}{l}\text { AGTCGCCACCCTGATGTCTC } \\
\text { CCTGGGGGAGAACCTGAAG }\end{array}$ & 223 \\
IL-12 $(\mathrm{p} 40)$ & $\begin{array}{l}\text { Sense } \\
\text { Antisense }\end{array}$ & $\begin{array}{l}\text { CCTGCTGGTGGCTGACGACAAT } \\
\text { CTTCAGCTGCAAGTTTTGGGT }\end{array}$ & 311 \\
ureA & $\begin{array}{l}\text { Sense } \\
\text { Antisense }\end{array}$ & $\begin{array}{l}\text { GCCAATGGTAATTAGTT } \\
\text { CTCCTTATTGTTTTAC }\end{array}$ & 411 \\
cagA & $\begin{array}{l}\text { Sense } \\
\text { Antisense }\end{array}$ & $\begin{array}{l}\text { GATAACGCTGTCGCTTCATACG } \\
\text { CTGCAAAAGATTGTTTGGCAGA }\end{array}$ & 409 \\
\hline
\end{tabular}

bp, base pair; IL, interleukin.

chemokine responses, ${ }^{16-20}$ more severe gastric inflammation and increased risk of peptic ulceration, gastric atrophy, and gastric cancer of the intestinal type. ${ }^{21-23}$

Recent studies on gastric mucosal expression of IL- $10^{1624-28}$ and IL-12 $2^{1326}$ in H pylori associated gastritis have given varying results. This may reflect both methodology and bacterial phenotype. No studies to date have fully characterised gastric mRNA expression of IL-12 in relation to cag status or peptic ulceration. In contrast to earlier studies ${ }^{16}{ }^{25}$ we have used semiquantitative techniques ${ }^{19}$ to investigate IL-12 (p40) and IL-10 mRNA expression levels in the gastric mucosa in relation to bacterial cag status, peptic ulceration, and histopathology.

\section{Methods}

PATIENTS

We studied 81 patients with dyspeptic symptoms (36 male and 45 female, age range 17 to 69 years, mean age 45.4 years). Patients who had received antisecretory agents, antibiotics, bismuth, or non-steroidal anti-inflammatory drugs (NSAID) within the previous two months were excluded. Patients who had received $H$ pylori eradication treatment were also excluded. Informed consent was obtained from all patients and the study was approved by the local clinical research ethics committee.

SAMPLE COLLECTION AND HISTOPATHOLOGY

During upper gastrointestinal endoscopy, multiple biopsy specimens were taken from the gastric antrum and corpus. One biopsy specimen from the antrum was used for the rapid urease test (CLO test, Delta West Pty, Australia). Two biopsy specimens from the antrum and corpus were snap frozen in liquid nitrogen and stored at $-80^{\circ} \mathrm{C}$ before RNA extraction. Two antral and corpus biopsies were taken for histological examination, including modified Giemsa staining for the identification of $H$ pylori. Specimens were examined without knowledge of the experimental results by one histopathologist (MFD). Chronic inflammation, polymorphonuclear activity, atrophy, intestinal metaplasia, and $H p y$ lori colonisation density were graded from 0 to 3 according to the updated Sydney system. ${ }^{29}$ The degree of antral predominance for these features was assessed by subtracting corpus scores from antral scores for each patient. ${ }^{30}$
RNA EXTRACTION AND REVERSE TRANSCRIPTION Total RNA was extracted from biopsy specimens using a cationic detergent based extraction method (Catrimox-14, Iowa Biotechnology), following the manufacturer's protocol. ${ }^{31}$ Isolated RNA was dissolved in $20 \mu \mathrm{l}$ of RNA solubilisation solution containing $20 \mathrm{U}$ of ribonuclease inhibitor (RNasin, Promega) and 20 $\mathrm{mM}$ dithiothreitol. To avoid genomic DNA contamination, RNA samples received deoxyribonuclease treatment using $1 \mathrm{U}$ of DNase ITM (Gibco BRL) before reverse transcription. Ten microlitres of each RNA sample were reverse transcribed with $0.5 \mu \mathrm{g}$ random hexamer (Random Primers, Promega), 120 U Moloney murine leukaemia virus reverse transcriptase (MMLV-RT, Promega), $50 \mathrm{mM}$ Tris$\mathrm{HCl}, 75 \mathrm{mM} \mathrm{KCl}, 3 \mathrm{mM} \mathrm{MgCl}, 1.0 \mathrm{mM}$ each dNTPs, and $20 \mathrm{U}$ RNasin, in a final volume of $20 \mu \mathrm{l}$. The mixture was incubated at $42^{\circ} \mathrm{C}$ for one hour, then heated to $95^{\circ} \mathrm{C}$ for five minutes and stored at $4^{\circ} \mathrm{C}$ until use.

PCR AND SEMIQUANTITATION OF PCR PRODUCTS The sequences of the oligonucleotide primer pairs used in this study are shown in table 1 . glyceraldehyde 3-phosphate dehydrogenase $(\mathrm{G} 3 \mathrm{PDH})$ and each of IL-10 $0^{32}$ and IL-12 $(\mathrm{p} 40)^{26}$ were coamplified in a duplex polymerase chain reaction (PCR). One microlitre of complementary DNA was added to the PCR reaction mixture containing $10 \mathrm{mM}$ Tris- $\mathrm{HCl}$ (pH 8.3), $50 \mathrm{mM} \mathrm{KCl}, 4.5 \mathrm{mM}$ (ureA) or 2.0 $\mathrm{mM}$ (IL-10, IL-12, and G3PDH) or $1.5 \mathrm{mM}$ (cagA) $\mathrm{MgCl}_{2}, 200 \mu \mathrm{M}$ each dNTPs, primer pairs (combined at a ratio of $1: 20$ pmol for G3PDH to IL-10 and 1:30 pmol for G3PDH to IL-12), and 1.0 U Taq DNA polymerase (Promega).

Amplification was performed in a thermal cycler: five minutes at $95^{\circ} \mathrm{C}$ (initial denaturation) followed by 35 cycles (IL-10, IL-12, and $\mathrm{G} 3 \mathrm{PDH}$ ) or 40 cycles (ureA and cagA) of one minute denaturation at $95^{\circ} \mathrm{C}$, one minute annealing at $50^{\circ} \mathrm{C}$ (ureA and cagA) or $55^{\circ} \mathrm{C}$ (IL-10 and G3PDH) or $60^{\circ} \mathrm{C}$ (IL-12 and $\mathrm{G} 3 \mathrm{PDH}$ ), and one minute extension at $72^{\circ} \mathrm{C}$. The final cycle included extension for five minutes at $72^{\circ} \mathrm{C}$. Negative and positive control amplifications were performed in each PCR series.

Randomly selected bacterial RNA was used for ureA and cagA PCR to check for bacterial genomic DNA contamination and no product was amplified. Products of PCR were electrophoresed on $2 \%$ agarose gel and visualised by ethidium bromide staining under ultraviolet light. The gel was run with a track containing loading buffer and negative control to act as a background track for subtraction during image analysis. The image was electronically captured and digitised using a UVP gel documentation system (GDS 5000; Ultra Violet Products). The peak height and the area measurements were determined for each band on the track using Gelbase software and the ratios of cytokines to G3PDH were calculated. ${ }^{33}$ 

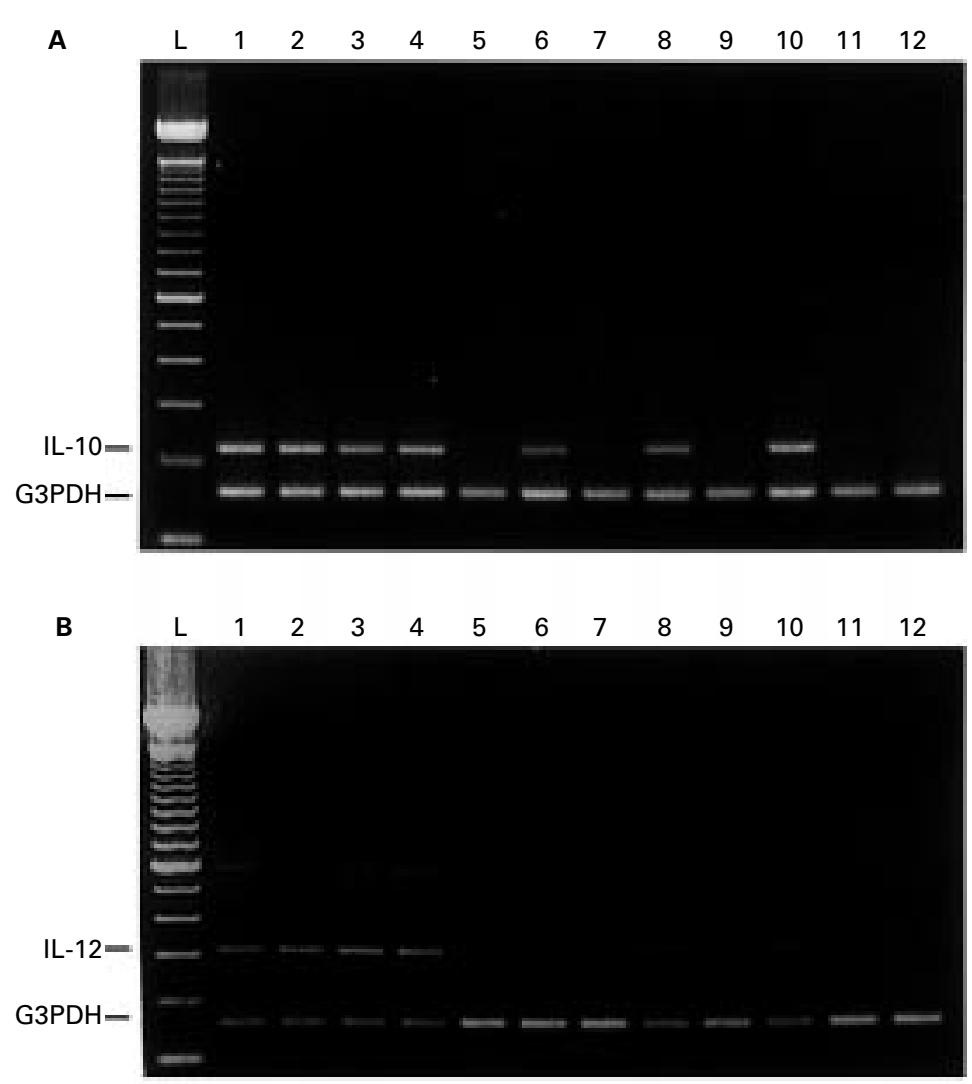

Figure 1 Representative reverse transcriptase polymerase chain reaction (RT-PCR) for (A) IL-10 and (B) IL-12 (p40) $m R N A$ in gastric antral biopsies. Lane L, 100 base pair ladder; lanes $1-4, H$ pylori ure $B$ positive, cag $A$ positive gastritis; lanes $5-8, H$ pylori ure $A$ positive, cag $A$ negative gastritis; lanes 9 and 10, H pylori negative gastritis; lanes 11 and 12, $H$ pylori negative normal mucosa.

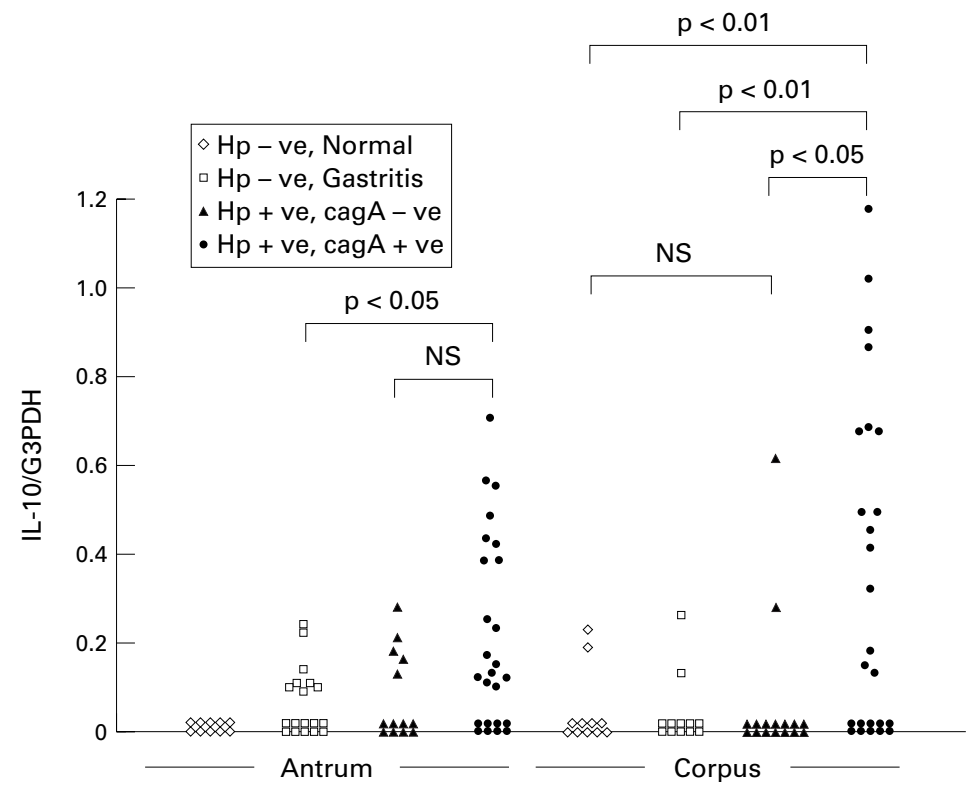

Figure 2 Expression of interleukin (IL)-10 mRNA in the gastric antral and corpus mucosa in $H$ pylori negative and positive patients.

STATISTICAL ANALYSIS

The $\chi^{2}$ test with Yates' correction was used to compare the frequencies of cytokine mRNA expression in different patient groups. Results of the ratios of cytokines to $\mathrm{G} 3 \mathrm{PDH}$ in different groups were compared by the Mann-
Whitney $U$ test. The relation between the IL-10 to G3PDH and IL-12 to G3PDH ratios and histological features was determined by the Pearson correlation coefficient. A p value of less than 0.05 was considered statistically significant.

\section{Results}

H PYLORI STATUS, HISTOLOGICAL FINDINGS, AND ENDOSCOPIC DIAGNOSIS

The patients were defined as $H$ pylori positive if at least one of CLO test, histological examination, or ureA reverse transcriptase polymerase chain reaction (RT-PCR) was positive. Forty seven of 81 patients $(58 \%)$ were $H$ pylori positive and 30 of these $(64 \%)$ were cagA positive by RT-PCR. Histologically, the antral biopsies of all $H$ pylori positive patients showed chronic active gastritis. In $34 \mathrm{H}$ pylori negative patients, 15 had histologically normal gastric mucosa and were classified as the normal control group. The other $19 \mathrm{H}$ pylori negative patients with some form of gastritis histologically were classified as the $H$ pylori negative gastritis group. This group consisted of 10 patients with chemical or reactive gastritis, seven with inactive chronic gastritis, and two with autoimmune type atrophic gastritis. Endoscopic findings in the patients studied were as follows: 12 patients (age range 27 to 68 years, mean age 48.8 years) had active duodenal ulcer or scar; five patients (age range 43 to 62, mean age 54.4) had gastric ulcer; and 64 patients (age range 17 to 69 , mean age 47.6) had no endoscopic evidence of ulceration. Thirty of 64 patients $(47 \%)$ without endoscopic ulcers and all of those with duodenal and gastric ulcers were $H$ pylori positive. Positivity for cagA gene did not differ in the three groups (duodenal ulcer, $67 \%$; gastric ulcer, $60 \%$; non-ulcer group, $63 \%$ ).

\section{IL-10 AND IL-12 (p40) mRNA EXPRESSION AND} H PYLORI INFECTION

In the 81 patients, antral biopsies were obtained from 66 and corpus biopsies from 64 for RT-PCR. Representative results of RT-PCR for IL-10 and IL-12 (p40) are shown in fig 1.

In the antral (A) and corpus (C) mucosa, positivity for IL-10 mRNA expression was significantly more frequent $(\mathrm{p}<0.05)$ in $H$ pylori positive patients (A, 58\%; C, 42\%) than in $H$ pylori negative patients (A, 29\%; C, 17\%). IL-10 mRNA expression (IL-10 to G3PDH ratio) in both antral and corpus mucosa was higher $(\mathrm{p}<0.01)$ in cagA positive infection than in normal control patients. IL-10 mRNA expression in cagA negative infection was not significantly different from uninfected control patients in either the antral or corpus mucosa (fig 2). Corpus IL-10 mRNA expression was greater $(\mathrm{p}<0.05)$ in cagA positive than in cagA negative infection (fig 2). In $\mathrm{H}$ pylori negative patients with chronic gastritis, IL-10 mRNA expression was not significantly different from the $H$ pylori negative control group in either the antral or the corpus mucosa (fig 2).

IL-12 (p40) mRNA positivity was more frequent in $H$ pylori positive patients (A, $29 \%$; C, $34 \%, \mathrm{p}<0.05)$ than in $H$ pylori negative 


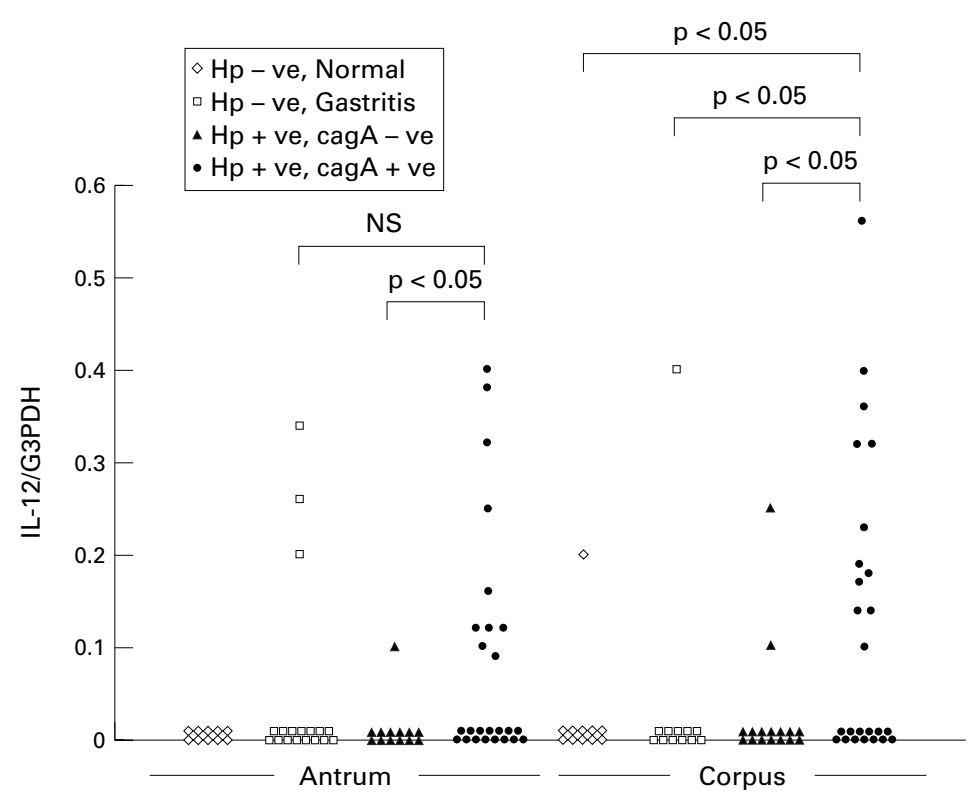

Figure 3 Expression of interleukin (IL)-12 (p40) $m R N A$ in the gastric antral and corpus mucosa in $H$ pylori negative and positive patients.

patients (A, 11\%; C, 9\%). IL-12 mRNA expression (IL-12 to G3PDH ratio) in both antral and corpus mucosa was greater $(\mathrm{p}<0.05)$ in cagA positive infection than in $H$ pylori negative normal control patients with histologically normal mucosa (fig 3). Both in the antral and corpus mucosa, IL-12 mRNA expression was greater $(\mathrm{p}<0.05)$ in cagA positive than in cagA negative infection. IL-12 mRNA expression in cagA negative infection was no different from that in uninfected patients with normal gastric mucosa. In cagA positive infection, there was a significant correlation between IL-10 and IL-12 mRNA expression in both the antral mucosa $(r=0.515, \mathrm{p}<0.01)$ and the corpus mucosa $(r=0.6, \mathrm{p}<0.005)$. This correlation was not observed in cagA negative infection. Among the $H$ pylori positive patients, no correlation was observed between IL-10 and IL-12 mRNA expression and chronic inflammation, polymorphonuclear cell activity, atrophy, intestinal metaplasia, and $H$ pylori colonisation density. Furthermore, there was no correlation between the degree of antrum predominant gastritis and mRNA expression of either cytokine. In $H$ pylori negative patients with chronic gastritis, the IL-12 to G3PDH ratios did not differ from the $H$ pylori negative control group (fig 3 ).

IL-10 AND IL-12 (p40) mRNA EXPRESSION AND ENDOSCOPIC DIAGNOSIS

In $H$ pylori infected patients, antral IL-12 mRNA expression was greater $(\mathrm{p}<0.05)$ in those with duodenal ulcer than in those without ulcers (fig $4 \mathrm{~A}$ ). In $H$ pylori positive patients with duodenal ulcer, six of seven patients with increased IL-12 mRNA expression in the antral mucosa were cagA positive. Interestingly, in $H$ pylori positive patients without ulcers, all patients with increased levels of IL-12 mRNA in the antral mucosa were also cagA positive. Positivity for IL-12 mRNA in
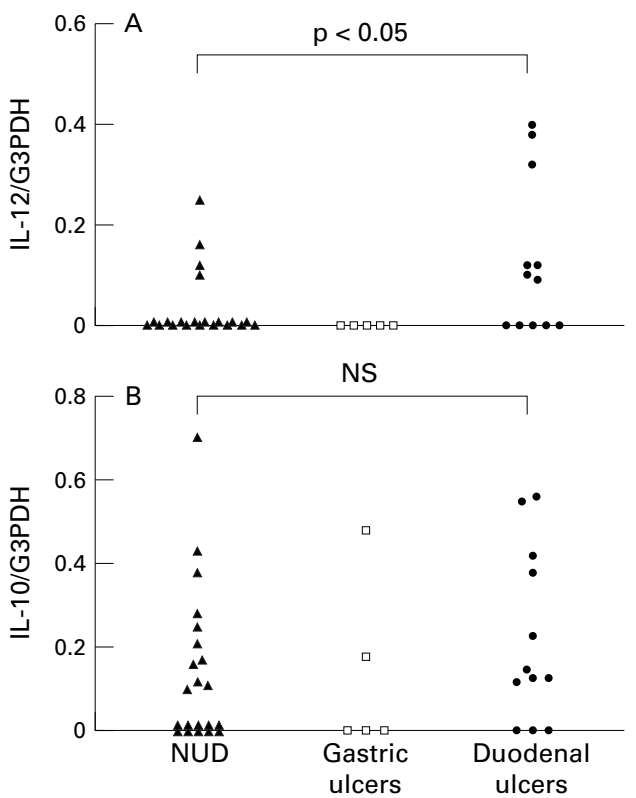

Figure 4 Expression of antral interleukin (IL)-12 (p40) $m R N A(A)$ and IL-10 $m R N A(B)$ in H pylori positive patients without ulceration (NUD) and with duodenal patients without ulceration (NUD) and with duodenal
ulcers or gastric ulcers (as the ratio of $I L-10$ or $I L-12$ to glyceraldehyde 3-phosphate dehydrogenase).

the antral mucosa was found more often $(\mathrm{p}<0.05)$ in patients with duodenal ulcer $(58 \%)$ than in those with gastric ulcer $(0 \%)$. IL-12 mRNA expression in the corpus mucosa was also more common in patients with duodenal ulcer $(50 \%)$ than in those with gastric ulcer $(25 \%)$ or without ulcers $(30 \%)$. The observed variation in IL-12 mRNA expression between patients with duodenal ulcers and gastric ulcers did not relate to any significant differences in gastric histopathology between the two groups. No difference was observed in IL-10 mRNA expression in relation to endoscopic diagnosis in either the antral mucosa (fig 4B) or the corpus mucosa.

\section{Discussion}

Current evidence from both human ${ }^{12-15}$ and murine studies ${ }^{2}{ }^{3}$ has shown that the $\mathrm{T}$ helper response in the gastric mucosa with chronic helicobacter infection has a predominantly Th1 phenotype, characterised by high IFN $\gamma$ and low IL-4 production. IL-12, which is produced by phagocytic cells, antigen presenting cells, and B cells in response to bacteria and bacterial products, plays an important role in the differentiation of Th1 cells. ${ }^{64-36}$ IL-12 deficient mice are defective in their ability to secrete IFN $\gamma$ in response to several antigens and to generate normal Th1 responses. ${ }^{37}$

In $H$ pylori gastritis, variable results have been reported on mucosal IL-12 mRNA expression. Karttunen et $a l^{26}$ and D'Elios et $a l^{12}$ observed increased gastric IL-12 mRNA expression in $H$ pylori infection; however, in another study no difference in IL-12 mRNA expression or biopsy IL-12 protein in $H$ pylori infection was found. ${ }^{27}$ In our study, IL-12 mRNA expression was increased in cagA positive $H$ pylori infected antral and corpus mucosa, but not in cagA negative infection, possi- 
bly accounting for earlier discrepant observations. Increased IL-12 in cagA positive infection may promote strong Th1 cell mediated responses, which are considered to be associated with increased mucosal damage. ${ }^{1}$ The important role of Th1 responses in mucosal damage has recently been demonstrated in the $\mathrm{H}$ felis infected mouse model. ${ }^{2}{ }^{3}$ Neutralisation of IFN $\gamma$ reduced the severity of gastric inflammation ${ }^{2}$ and passive transfer of Th1 cell lines exacerbated gastritis. ${ }^{3}$

Recently, D'Elios et al suggested that gastric Th1 responses are more frequent in patients with peptic ulcer disease than in those with chronic gastritis only. ${ }^{12}$ Their study investigated the cytokine profile of $H$ pylori specific $\mathrm{T}$ cell clones generated from cagA positive $H p y$ lori infected gastric biopsies. The majority of $H$ pylori-specific $\mathrm{T}$ cell clones from the antral mucosa of six patients with peptic ulceration showed a Th 1 profile secreting both IFN $\gamma$ and tumour necrosis factor $\alpha(\mathrm{TNF} \alpha)$. In contrast, $64 \%$ of clones from five non-ulcer patients with chronic gastritis expressed a Th0 profile, secreting both Th1 and Th2 cytokines following exposure to $H$ pylori antigens. ${ }^{12}$ In our study, antral IL-12 mRNA expression was increased in the majority of $\mathrm{H}$ pylori infected patients with duodenal ulcers but not in those with gastric ulcers or without ulcers. This result suggests that in patients with duodenal ulcer, mucosal Th1 responses may predominate and be a factor in the pathogenesis of duodenal ulceration.

In many populations the presence of cagA positive $H$ pylori strains has been linked to increased risk of peptic ulceration. ${ }^{2125} 3839$ The frequency of cagA positive strains globally is highly variable ${ }^{40}$ and in some populations with a high frequency of cagA positive strains an association with ulceration has not been observed. ${ }^{41}$ In our study, positivity for gastric IL-12 mRNA was observed in approximately half of those infected with cagA positive strains. It will be interesting to examine gastric IL-12 mRNA expression, the cagA status of $H$ pylori, and peptic ulceration in other populations.

Th1 responses may contribute to mucosal damage directly by causing cytotoxic damage to epithelial cells or by changing epithelial phenotype, with increased expression of HLA class II molecules. ${ }^{42}$ This phenotypic change, and the changes in epithelial permeability that will be mediated by IFN $\gamma$ and $\mathrm{TNF}^{43}{ }^{44}$ may facilitate enhanced antigen presentation by both epithelial cells and intramucosal antigen presenting cells causing an exacerbation of mucosal inflammation. The predominate Th1 responses in patients with duodenal ulcer may also be relevant to the perturbations in gastric physiological responses associated with ulceration. ${ }^{45}$ A recent in vitro study showed that IFN $\gamma$ stimulates gastrin secretion from canine antral G cells. ${ }^{46}$

Anti-inflammatory cytokines such as IL-10 are important in the downregulation of excessive proinflammatory responses ${ }^{10}$ and inhibit Th1 differentiation by suppressing IL-12 secretion from accessory cells. ${ }^{6911}$ Recently, Groux et al reported that IL-10 stimulates the generation of a $\mathrm{T}$ cell subset, designated a $\mathrm{T}$ regulatory cell 1 ( $\operatorname{Tr} 1)$, which produces high levels of IL-10 and has immunoregulatory properties. ${ }^{47} \mathrm{Tr} 1$ clones can prevent $\mathrm{T}$ cell mediated colitis in mice with severe combined immune deficiency, ${ }^{47}$ showing the importance of IL-10 for the maintenance of $\mathrm{T}$ cell tolerance in the gastrointestinal mucosa. IL-10 mRNA expression is increased in human intestinal mucosal cells in inflammatory bowel disease. ${ }^{48}$ In patients with inflammatory bowel disease, particularly Crohn's disease, chronic intestinal inflammation is characterised by Th1 predominant responses. ${ }^{48} 49$ IL-10 may downregulate the increased secretion of proinflammatory cytokines in such patients, ${ }^{50}$ and a similar role is feasible in helicobacter associated gastritis. Recently, Berg et al reported that $H$ felis infected IL-10 deficient, but not wild type, mice develop a severe hyperplastic gastritis with marked epithelial proliferation and dedifferentiation. ${ }^{51}$ This result strongly suggests that IL-10 may be a key factor in the host's immune responses to gastric helicobacter infection.

There have been variable reports on gastric expression of IL-10 mRNA ${ }^{16-27}$ and protein $^{252728}$ in $H$ pylori infection. Some studies $^{26}$ have not assessed IL-10 mRNA directly in snap frozen biopsies as in this study, but have examined mRNA expression in enzymatically extracted gastric cells. The cell isolation procedures are likely to induce cytokine expression. Measurement of cytokines in biopsy homogenates ${ }^{27} 28$ is also likely to be complicated not only by the sensitivity of the cytokine ELISA, but also by the presence of mucosal autoantibodies to cytokines ${ }^{52}$ and cytokine receptors. ${ }^{53}$ In agreement with two earlier studies, ${ }^{16}{ }^{25}$ we observed increased IL-10 mRNA expression in $H$ pylori infected gastric mucosa. Increased IL-10 mRNA was seen predominantly in patents with cagA positive infection; thus differences in cag status could account for earlier variable results. Several reports have shown that infection with cagA positive strains is associated with increased gastric $\mathrm{C}-\mathrm{X}-\mathrm{C}$ chemokine expression and severe gastric inflammation. ${ }^{16-20}$ IL-10, which inhibits the secretion of chemokines from macrophages and polymorphonuclear cells, ${ }^{54}$ may be an important defence mechanism protecting against enhanced $\mathrm{C}-\mathrm{X}-\mathrm{C}$ responses in cagA positive infection.

Interestingly recent studies have shown that IL-12 can induce $\mathrm{T}$ cells to secrete IL-10. ${ }^{55}$ Our finding of a significant correlation between IL-10 and IL-12 mRNA expression in cagA positive $H$ pylor $i$ infection suggests that IL-12 may limit its own production by induction of IL-10 as a negative feedback for IL-12 induced Th1 responses. In our study, no difference was observed in IL-10 mRNA expression in $H$ pylori infected patients in relation to peptic ulceration. This suggests that lack of IL-10 is unlikely to be a contributory factor in peptic ulceration. 
CONCLUSIONS

Expression of both IL-10 and IL-12 mRNA is increased in cagA positive $H$ pylori infection. Increased expression of IL-12 mRNA in cagA positive infection may polarise the differentiation of naive $\mathrm{T}$ cells into Th 1 cells and promote cell mediated responses. In patients with duodenal ulcer, IL-12 regulated mucosal Th1 responses may predominate and play a role in the pathogenesis of duodenal ulceration. IL10, which inhibits the secretion of proinflammatory cytokines and chemokines, may be an important defence mechanism protecting against the exaggerated C-X-C and Th1 responses in cagA positive infection. The balance between induction of proinflammatory cytokines and stimulation of anti-inflammatory cytokines may be important in disease outcome.

We thank Dr S Farmery for her helpful discussions. This study was undertaken with financial support from the European Commission (contract No ICI8CT950024) and Yorkshire Cancer Research. The study was presented in part at the British
Society of Gastroenterology, the AGA and the XIth InterSociety of Gastroenterology, the AGA and the XIth Inter-
national Workshop on Gastroduodenal Pathology and Heliconational Workshop on Gastroduodenal Pathology and Helicobacter pylori, and published in abstract form in Gut and Gut (1998;43(suppl 2):A27)

1 Crabtree JE. Role of cytokines in pathogenesis of Helicobacter pylori-induced mucosal damage. Dig Dis $\mathrm{Sci}$ 1998;43:46-55S

2 Mohammadi M, Czinn S, Redline R, et al. Helicobacterspecific cell-mediated responses display a predominant Th1 phenotype and promote a delayed-type hypersensitivity response in the stomach of mice. F Immunol 1996;156: ity response

3 Mohammadi M, Nedrud J, Redline R, et al. Murine CD4 T-cell response to Helicobacter infection: TH1 cells
enhance gastritis and $\mathrm{TH} 2$ cells reduce bacterial load. Gasenhance gastritis and TH2 cells
troenterology 1997;113:1848-57.

4 Del Prete G. The concept of type- 1 and type- 2 helper T cells and their cytokines in humans. Int Rev Immunol 1998; 16:427-55

5 Paul WE, Seder RA. Lymphocyte responses and cytokines. Cell 1994;76:241-51.

6 Trinchieri G. Interleukin-12: a proinflammatory cytokine with immunoregulatory functions that bridge innate resistance and antigen-specific adaptive immunity. Annu Rev Immunol 1995;13:251-76

7 D'Andrea A, Rengaraju M, Valiante NM, et al. Production of natural killer cell stimulating factor (NKSF/IL-12) by peripheral blood mononuclear cells. $\mathcal{F}$ Exp Med 1992;1 176: peripher.

8 Fiorentino DF, Bond MW, Mossmann TR. Two types of mouse T helper cells. IV. Th2 clones secrete a factor that inhibits cytokine production by Th1 clones. 7 Exp Med inhibits cytokine p

9 Moore KW, O'Garra A, De Waal Malefyt R, et al. Interleukin-10. Annu Rev Immunol 1993;11:165-90.

10 D'Andrea A, Aste-Amezaga M, Valiante NM, et al. Interleukin 10 (IL-10) inhibits human lymphocyte interferon gamma production by suppressing natural killer cel stimulatory factor/IL-12 synthesis in accessory cells. $\mathcal{F}$ Exp Med 1993;178:1041-8.

11 De Vries JE. Immunosuppressive and anti-inflammatory properties of interleukin 10. Ann Med 1995;27:537-41.

12 D'Elios MM, Manghetti M, Almerigogna F, et al. Differen cytokine profile and antigen-specificity repertoire in Helicobacter pylori-specific T cell clones from the antrum of chronic gastritis patients with or without peptic ulcer. Eur f Immunol 1997;27:1751-5.

13 D'Elios MM, Manghetti M, De Carli M, et al. T helper 1 effector specific for Helicobacter pylori in the gastric
antrum of patients with peptic ulcer disease. $\mathcal{F}$ Immunol antrum of patients

14 Karttunen R, Kattunen T, Ekre HPT, et al. Interferon gamma and interleukin 4 secreting cells in the gastric antrum in Helicobacter pylori positive and negative gastritis. Gut 1995;36:341-5.

15 Bamford KB, Fan X, Crowe SE, et al. Lymphocytes in the human gastric mucosa during Helicobacter pylori have a Thelper cell 1 phenotype. Gastroenterology 1998;114:48292 .

16 Peek RM, Miller GG, Tham KT, et al. Heightened inflammatory response and cytokine expression in vivo to cagA Helicobacter pylori strains. Lab Invest 1995;71:760-70.

17 Crabtree JE, Farmery SM, Lindley IJD, et al. CagA cytotoxic strains of Helicobacter pylori and interleukin-8 in cytotoxic strains of Helicobacter pylori and interleuki

18 Crabtree JE, Covacci A, Farmery SM, et al. Helicobacter pylori induced interleukin-8 expression in gastric epithelial cells is associated with CagA positive phenotype. 7 Clin Pathol 1995;48:967-9.

19 Shimoyama T, Everett SM, Dixon MF, et al. Chemokine mRNA expression in gastric mucosa is associated with Helicobacter pylori cagA positivity and severity of gastritis. f Clin Pathol 1998;51:765-70.

20 Yamaoka Y, Kita M, Kodama T, et al. Chemokines in the gastric mucos

21 Covacci A Censini S, Bugnoli $M$, et al Molecular characterization of the $128-\mathrm{kDa}$ immunodominant antigen
of Helicobacter pylori associated with cytotoxicity and duodenal ulcer. Proc Natl Acad Sci USA 1993;90:5791-5.

22 Kuipers EJ, Perez-Perez GI, Meuwissen SG, et al. Helicobacter pylori and atrophic gastritis: importance of the cagA status. F Natl Cancer Inst 1995;87:1777-80.

23 Blaser MJ, Perez-Perez GI, Kleanthous H, et al. Infection with Helicobacter pylori strains possessing cagA is associated with an increased risk of developing adenocarcinoma of the stomach. Cancer Res 1995;55:2111-15.

24 Bodger K, Wyatt JI, Heatley RV. Gastric mucosal secretion of interleukin-10: relations to histopathology, Helicobacter pylori status, and tumour necrosis factor- $\alpha$ secretion. Gut 1997;40:739-44

25 Yamaoka Y, Kita M, Kodama T, et al. Helicobacter pylori cagA gene and expression of cytokine messenger RNA in gastric mucosa. Gastroenterology 1996;110:1744-52.

26 Karttunen RA, Karttunen TJ, Yousfi MM, et al. Expression of mRNA for interferon-gamma, interleukin-10, and interleukin-12 (p40) in normal gastric mucosa and in mucosa infected with Helicobacter pylori. Scand 7 Gastroenterol 1997;32:22-7.

27 Haeberle HA, Kubin M, Bamford KB, et al. Differential expression of interleukin-12 (IL-12) and IL-10 by live and killed Helicobacter pylori in vitro and association of IL-12 production with gamma interferon-producing $\mathrm{T}$ cells in human gastric mucosa. Infect Immun 1997;65:4229-35.

28 Yamaoka Y, Kita M, Kodama T, et al. Induction of various cytokines and development of severe mucosal inflammation by cagA gene positive Helicobacter pylori strains. Gut 1997;41:442-51.

29 Dixon MF, Genta RM, Yardley JH, et al. Classification and grading of gastritis. Am 7 Surg Pathol 1996;20:1161-81.

30 Warburton VJ, Everett S, Mapstone NP, et al. Clinical and histological associations of cagA and vacA genotypes in Helicobacter pylori gastritis. F Clin Pathol 1998;51:55-61.

$31 \mathrm{McF}$ arlane DE, Dahle CE. Isolating RNA from whole blood-the dawn of RNA-based diagnosis? Nature 1993; $362: 186-8$.

32 Klava A, Windsor ACJ, Farmery SM, et al. Interleukin-10, a role in development of postoperative immunosuppression. Arch Surg 1997;132:425-9.

33 Farmery SM, Crabtree JE. Host response to H. pylori: molecular analysis of cytokine gene expression. In: Clayton $\mathrm{CL}$, Mobley HL, eds. Helicobacter pylori protocol. New Jersey: Humana Press, 1997:225-34.

34 Manetti R, Parronchi P, Giudizi MG, et al. Natural killer cell stimulatory factor (NKSF/IL-12) induces Th1-type specific immune responses and inhibits the development of IL-4 producing Th cells. f Exp Med 1993;177:1199-204.

35 Manetti R, Gerosa F, Giudizi MG, et al. Interleukin-12 induces stable priming for interferon-gamma (IFNgamma) production during differentiation of human $\mathrm{T}$ helper (Th) cells and transient IFN-gamma production in established Th2 cell clones. 7 Exp Med 1994;179:1273-83.

36 Trinchieri G. Proinflammatory and immunoregulatory functions of interleukin-12. Int Rev Immunol 1998;16:36596.

37 Magram J, Connaughton SE, Warrier RR, et al. IL-12deficient mice are defective in IFN-gamma production and type 1 cytokine responses. Immunity 1996;4:471-81.

38 Crabtree JE, Taylor JD, Wyatt JI, et al. Mucosal IgA recognition of Helicobacter pylori $120 \mathrm{kDa}$ protein, peptic ulceration and gastric pathology. Lancet 1991;338:332-5.

39 Weel JFL, van der Hulst RWM, Gerrits Y, et al. The interrelationship between cytotoxin-associated gene A, vacuolating cytotoxin and Helicobacter pylori-related diseases. 7 Infect Dis 1996;173:1171-5.

40 Webb PM, Crabtree JE, Forman D, et al. Gastric cancer, cytotoxin-associated gene-A positive Helicobacter pylori and serum pepsinogens: an international study. Gastroenterology 1999;116:269-76.

41 Pan ZJ, van der Hulst RWM, Feller M, et al. Equally high prevalence of infection with cagA-positive Helicobacter pylori in Chinese patients with peptic ulcer disease and chronic gastritis-associated dyspesia. f Clin Microbiol 1997; 35:1344-7.

42 Valnes K, Huitfeldt HS, Brandtzaeg P. Relation between T cell number and epithelial HLA class II expression quantified by image analysis in normal and inflamed human gastric mucosa. Gut 1990;31:647-52.

43 Mullin JM, Snock KV. Effect of tumor necrosis factor on epithelial tight junctions and transepithelial permeability. Cancer Res 1990;50:2172-6.

44 Madara JL, Stafford J. Interferon-gamma directly affects barrier function of cultured intestinal monolayers. 7 Clin Invest 1989;83:724-7.

45 El-Omar EM, Penman ID, Ardill JES, et al. Helicobacter pylori infection and abnormalities of acid secretion in patients with duodenal ulcer disease. Gastroenterology 1995;109:681-91. 
46 Lehmann FS, Golodner EH, Wang J, et al. Mononuclear cells and cytokines stimulate gastrin release from canine antral cells

47 Groux H, O'Garra A, Bigler M, et al. A CD4+ T-cell subset inhibits antigen-specific T-cell responses and prevents colitis. Nature 1997;389:737-41

48 Niessner M, Volk BA. Altered Th1/Th2 cytokine profiles in the intestinal mucosa of patients with inflammatory bowel disease as assessed by quantitative reversed transcribed polymerase chain reaction (RT-PCR). Clin Exp Immunol 1995;101:428-35.

49 Monteleone G, Biancone L, Marasco R, et al. Interleukin 12 is expressed and actively released by Crohn's disease intestinal lamina propria mononuclear cells. Gastroenterology 1997;112:1169-78

50 Schreiber S, Heinig T, Thiele H-G, et al. Immunoregulatory role of Interleukin 10 in patients with inflammatory bowel disease. Gastroenterology 1995;108:1434-44.

51 Berg DJ, Lynch NA, Lynch RG, et al. Rapid development of severe hyperplastic gastritis with gastric epithelial dedifferentiation in Helicobacter felis-infected IL-10-/- mice. Am $\mathcal{F}$ Pathol 1998;152:1377-86.

52 Crabtree JE, Peichl P, Wyatt JI, et al. Gastric interleukin-8 and IgA IL-8 autoantibodies in Helicobacter pylori infection. Scand f Immunol 1993;37:65-70.

53 Bonner JC, Brody AR. Cytokine-binding proteins in the lung. Am $\mathcal{F}$ Physiol 1995;268:L869-78.

54 Kasama T, Strieter RM, Lukacs NW, et al. Regulation of neutrophil-derived chemokine expression by IL-10. $\mathcal{f}$ Immunol 1994;152:3559-69.

55 Meyaard L, Hovenkamp E, Otto SA, et al. IL-12-induced IL-10 production by human T cells as a negative feedback for IL-12-induced immune responses. F Immunol 1996; 156:2776-82. 